\title{
The Paradox in the Political Economy of Land Grabbing in Africa as Medium of Exchange and Its Implication on States
}

\author{
Mukhtar Imam \\ Zakari Ismail Momoh \\ Department of International Relations and Diplomacy \\ Baze University \\ Abuja-Nigeria
}

\begin{abstract}
The foremost definition of the global land grab refers to acquisition of land in large scale - be it purchase or lease for the purpose of agriculture etc. by foreign investors. The term has been extended to also cover transnational commercial land transactions and domestic deals and highlights the commercial nature of the transactions regardless of scale and output market. It is from the foregoing that this paper tries to make an analytical $x$-ray of the intricacies and controversies surrounding the issue of land grab and to also look closely at the dynamics of its medium of exchange as it pertains to foreign investors and local land owners in parts of Africa. The paper makes a practical indepth analysis of the issue from a pragmatic standpoint hence employing case studies. The paper relies largely on desk research but also adopts quantitative data gathered from field survey by other research institutions and individuals. The paper deduced that the political economy of land grab is largely detrimental to the host countries and the local populace at large and recommends amongst others that governments of local communities and states within Africa and other regions where this is prevalent must rise up to the occasion and secure the land of its people which is a great assert and is of significant importance due to its value. However genuine businesses in the form of foreign direct investment must be allowed to thrive as no country can survive in isolation without private sector involvement.
\end{abstract}

Keywords: Paradox, Political Economy, Land Grabbing, Medium of Exchange, Implication

Preamble:

The foremost definition of the global land grab refers to acquisition of land in large scale - be it purchase or lease - for the purpose of agriculture etc. by foreign investors. The term has been extended to also cover transnational commercial land transactions and domestic deals and highlights the commercial nature of the transactions regardless of scale and output market. From the foregoing it could be deduced that land grabbing involves taking possession or control of land belonging to a group of people in a geographical area - particularly by external or foreign parties' - at a disproportionate size in comparison to the average land holding in the area. ${ }^{1}$ Over the past couple of years, the phenomenon of land has been a recurrent decimal especially across Africa. Land grabbing has been on the horizon for centuries now and has in recent times assumed several forms and dimensions, although it is perceived to have only come to the fore both in the academia and international media. It has been seen to have tremendous economic, environmental and social impacts, which often more than not results in discord and conflict between the aborigines and foreigners, engineered by displacement and dispossession of; local people's land, loss of access, threat to livelihood and environmental degradation. ${ }^{2}$ The International Food Policy Research Institute (IFPRI) estimated that during the period 2005-2009, land grabbing affected about 20 million ha worldwide. ${ }^{3}$ A number of factors influencing this phenomenon include; the impact of the global crisis, food security, and climate change, the financial crisis, globalization, the liberalization of land markets and increased foreign direct investment e.g mining, agri-business, biofuel production etc. ${ }^{4}$

\footnotetext{
${ }^{1}$ S. Borras\& J. Franco; 2009. Towards a broader view of the politics of global land grab

${ }^{2}$ Yasmi Y. Kelly L. \& Enters, T.; 2010. Conflict over forest \& Land in Asia: Impacts, causes \& management RECOFTC, Bangkok, Thailand

${ }^{3}$ Borras Jr. S.M \& Franco, J.C; 2011.Political dynamics of land grabbing in southeast Asia: understanding Europe's role. Transnational institute, Amsterdam, The Netherlands.

${ }^{4}$ Schneider A.E; 2011; What Shall we do without our land? Land grab resistance in rural Cambodia in: LDPI International Conference on global land grabbing.
} 


\section{Foreign land acquisition}

Media are reporting large scale land acquisition by foreigners in Africa and other continents on an almost daily basis. ${ }^{5}$ More reliable information however is lacking with 'quantifications of the phenomenon, such as its scale and whether it is in fact on the rise still thin on the ground' ${ }^{6}$. This could be in part due to the noted unwillingness of both governments and business interests' to fully disclose information on negotiations and deals made. ${ }^{7}$ Within the last year several organizations including the United Nations 'specialized agencies and NGOs, have started to document and quantify the problem. A 2009 study titled "Land grab or development opportunity?" jointly produced by the Food and Agriculture Organization of the United Nations (FAO), the International Fund for Agricultural Development (IFAD) and the International Institute for Environment and Development (IIED), analyzed land acquisitions of 1000 hectares or more between 2004 and 2009 from four countries: Ethiopia, Ghana, Madagascar and Mali. According to the study, about two million hectares of land across the four countries have been signed over to foreign interests, including a 10,000-hectare project in Mali and a450,000-hectare plantation for agro-fuels in Madagascar. ${ }^{8}$ IIED identified accumulative increase in land acquisition in the four countries with the past five years seeing an upward trend in both project numbers and allocated land areas. It also identifies further growth of these activities. In July 2009 for example the Government of Ethiopia marked out 1.6 million ha of land, extendable to 2.7 million, for investors willing to develop commercial farms. The size of single acquisitions can be very large. Allocations include a 452, 500ha agro-fuels project in Madagascar, a 150,000ha livestock project in Ethiopia and a 100,000ha irrigation project in Mali. Investors include private sector (banks, agribusiness, investment companies, institutional investors, trading companies, mining companies), and in some cases Governments (directly or indirectly), through sovereign funds and domestic investors. David Hallam, Deputy Director at the Trade and Markets Division of FAO estimates that in the last three years 20 million hectares have been acquired by foreign interests in Africa specifying that the proportion of land under foreign control remains a relatively small proportion of total land areas- for instance around one percent in Ethiopia or Sudan. ${ }^{9}$ In Africa, Malagasy Law No 2007-036 for instance stipulates that 'foreign natural or legal entities cannot directly have land accesses. ${ }^{10}$ However they are free, without any prior authorization, to agree to renewable perpetual lease which duration cannot exceed ninety nine years'. Equally, in Ethiopia, for example, the Government owns all the land, which is leased for periods from 20 to 45 years. ${ }^{11}$ Such leases vary in price depending on land use etc. ${ }^{12} \mathrm{~A}$ number of different factors have prompted this growing trend of land acquisitions. ${ }^{13}$ The increasing pressure to produce agro-fuels as an alternative to fossil fuels is reported as creating an 'artificial demand (for agro-fuels) that is unprecedented among cash crops, and which is likely to persist beyond the usual length of a "commodity boom" cycle'. ${ }^{14}$

\footnotetext{
${ }_{5}^{5}$ Zoomers A; 2010.Globalization \& the foreignization of Space: Seven processes, during the current global land grab.Journal of peasant studies.

${ }^{6}$ See Land grabs' in Africa: can the deals work for development, IIED briefing, September 2009. Available athttp://www.iied.org/pubs/pdfs/17069IIED.pdf

${ }^{7}$ See The Growing Demand for Land - risks and opportunities for smallholder farmers, Discussion Paper and Proceeding Report of the Governing Council Round Table held in conjunction with the Thirty-second Session of IFAD's Governing Council, IFAD, May 2009. Available at: http://www.un.org/esa/dsd/resources/res_pdfs/csd-17/csd17_crp_land.pdf

${ }^{8}$ See Land grabs' in Africa: can the deals work for development? IIED briefing note September 2009. Available athttp://www.iied.org/pubs/pdfs/17069IIED.pdf

${ }^{9}$ See Foreign Investment in Developing Country Agriculture - Issues, Policy Implications and International Response. David Hallam. Paper presented at the Global Forum on International Investment, OECD, 7-8December 2009.

${ }^{10}$ See 'Land grabs' in Africa: can the deals work for development? IIED briefing note September 2009. Available at http://www.iied.org/pubs/pdfs/17069IIED.pdf

${ }^{11}$ See Foreign Direct Investment in the Agricultural Sector in Ethiopia, Eco Fair Trade Dialogue: Discussion paperNo 12 by Lucie Weissleder, University of Bonn, Heinrich Boll Stiftung, Misereor, October 2009. Available athttp://www.ecofairtrade.org/pics/en/FDIs_Ethiopia_15_10_09_c.pdf

${ }^{12}$ See Foreign Direct Investment in the Agricultural Sector in Ethiopia, EcoFair Trade Dialogue: Discussion paperNo 12 by Lucie Weissleder, University of Bonn, Heinrich Boll Stiftung, Misereor, October 2009. Available athttp://www.ecofairtrade.org/pics/en/FDIs_Ethiopia_15_10_09_c.pdf

${ }^{13}$ Several NGO/IGO publications on this topic recognise the increasing demand for biofuels. In its report TheGreat Land Grab, the Oakland Institute claims the use and production of biofuels is rocketing(http://www.oaklandinstitute.org/pdfs/LandGrab_final_web.pdf)

${ }^{14}$ See Fuelling exclusion? The biofuels boom and poor people's access to land, IIED and FAO, 2008, page 7.Available at http://www.iied.org/pubs/pdfs/12551IIED.pdf 
Other contributing factors are the global food crisis and the financial crisis. Wealthy but resource-poor countries have turned to large-scale acquisitions of land to outsource food production and achieve food security. This in turn has also led private investors, including large investment funds, to acquire land for merely speculative motives, convinced that the price of arable land will continue to rise in the future. In its World Investment Report, UNCTAD also notes that commitment to meet the MDG-1 target has encouraged countries to step up or promote agricultural investment, including by the domestic private sector and transnational corporations (TNCs). ${ }^{15}$

\section{The Nigeria Scenario}

Nigeria the world largest black race is the most populous in the African continent with the total land mass of about $923,768 \mathrm{~km} 2$ with the area square miles of $356,667 \mathrm{~m} 2$ located in West Africa gulf of guinea. The population of Nigeria stand over 200.96 million as at 2019 ranking $7^{\text {th }}$ largest in the world, (NBS 2019). A research conducted by World Bank in 2016 shows that about $51 \%$ of this population leaves in rural area thereby making them depend mainly on land resources for job creation and human's survival. Suffice to say that despite the insurgency that has ravaged the county since 2009, the country continue to attract commercial interest from foreign investors because of fertility of the soil and almost continues rainfall throughout the year particularly the south east and south western regions. The government guest for food security, sufficiency, massive job creation has made Nigerian land vulnerable to grabbers by foreign investment in agricultural sector.

In northern Nigeria, about 300-square kilometer was grabbed by the US based food and agricultural company (dominion farm) for rice plantation in the area. It was reported that both Nigeria government and G8's fully backed the grabbed meant to enhance food security and livelihood for small farmers in Nigeria and the rest of African continent. with this development, approximately 45,000 peoples land will be affected, the report by GRAN, an international right group that support small farmers, along with global justice now ERA-FOEN and CEED voice out the plight of those local farmers who claimed that their grabbed land was used for various production such as millet, yam, soya beans, cassava even fish farming and rearing of animals etc. The grabbers have thrown them to the street begging without prior information, no adequate compensation in conformity with labor law and international best practice. Another case of 12,000 hectares' grabbed by Chinese investors (lee group) in conjunction with the Jigawa state government remain fresh in the heart of the local and indigenous owners. The grabbed land was purportedly meant for Chinese company to set up a sugar cane plantation with a view to setting up sugar factor in the state.

According to the PREMIUM TIMES, the grabbed land affected 22 largely farming villages and 27 Fulani hamlets which will displace "over 20 million villagers, three million other animals such as goat ,sheep, and cattle" as for the land owners, the action of government and lee group will lead us to high rate of unemployment, poverty, youth unrest , armed robbery and subsequently can generate to terrorism. In views of the above consequences, the villagers' were ready to defend their land "with everything at their disposal".

The land in question belong to over 150,000 individuals who have threatens to mobilize neighboring villagers to join in defending their children future from becoming refugee in their own land. One of the victims Mr. Bello said "we want to raise our children as good, law abiding citizens. It is through this land that we take care of them, pay their school fees and help them to get married and raise their families too.

\section{Medium of Exchange: Strong Policies}

Nigeria government must develop a sound capacity to strongly stand and negotiate on win-win term between the local farmers and the foreigners, spontaneous follow up on oversight to monitor the agreed term for the country to take full advantage of this massive takeover of Nigeria land for investment. for equity sack, local community land owners or their representative should be fully integrated before and after negotiation, environmental experts, foreign community liaison officer and representative of government of the host country must be involved to fulfill the right of humans, land right and laborlenvironmental right . (de schutter) if Nigeria government maintain the above judiciously with strong legislation, land grab will not only create massive job but will add value to the quality of life of the indigent and neighboring communities thereby reducing rural urban migration, and crime rate and youth restiveness in the host community .

\footnotetext{
${ }^{15}$ See World Investment Report, Transnational Corporations, Agricultural Production and Development,UNCTAD, 2009, page 103. Available at:http://www.unctad.org/en/docs/wir2009_en.pdf
} 


\section{The Ugandan case study}

For 9 years, FIAN has investigated and documented a case involving the forced eviction of 401 families (approximately 2041 individuals) in August2001 following the Government leasing the land to a German coffee trader to establish a plantation under its local subsidiary Kaweri Coffee Plantation Ltd. ${ }^{16}$ The families affected were not adequately consulted during the land allocation process. Moreover during the eviction, the army demolished houses, destroyed property, and confiscated staple crops such as cassava and potatoes. Since the eviction, only $2 \%$ of the evictees have been compensated but not adequately. As of 2009 most of those evicted are still living on the border of the plantation and it remains uncertain whether they will be allowed to stay there. They only have small plots of land for farming that are insufficient to provide their families with food for the whole year. One of the evictees notes 'having no land for us means to have no food'. So far those evicted have not been adequately compensated for their loss of livelihoods. In addition to the lack of clarity concerning the plots on which Kaweri pretends to have a claim, the government does not recognize and protect the right of the occupants over their traditional land. This is despite the provisions of Ugandan law on this, which recognizes both the bonafide and lawful occupants. Under the Land Act of 1998 dispossessions can only be carried out in exchange for compensation, and even illegal occupants may not be displaced against their will after a period of 12 years if within this time the proprietor has not told them to leave the land (bonafide occupants). Moreover the two percent that were compensated with new land were allocated less land than they held previously and in some instances plots were allocated twice. Most of the community had to rely on the solidarity of other villages to resettle. There is no adequate access to clean water and local infrastructure. In August 2008, a new report about the living conditions of the evictees was published. This follow up survey, conducted by Action Aid, has found that the situation of the affected communities is further deteriorating, particularly with regard to the housing conditions. ${ }^{17}$

\section{Land confiscation and medium of exchange}

Employment: Following their eviction some farmers/peasants were employed as casual laborers/day laborers by the coffee plantation. They receive 2000USH (about 1 USD) per day for a fixed amount of work. If the work has not been completed, they do not receive the money. Often therefore the laborers receive 1USD for two days work. Some workers reported waiting weeks before being paid. The management claims that the workers are employed by subcontractors. They also maintain that the wages are adequate using the wages in the tea and sugar section as a defense. Wages are a problem in Uganda. Trade unions are weak and there is no minimum wage. On 1 March 2004 the workers went on strike to protest at the bad working conditions at the plantation. The plantation's management called in riot police who used massive violence to break up the strike. The Kaweri Plantation made the affected families dependent on wages by taking their land. Prior to the eviction they were able to work independently and earned significantly more than the wages they currently receive. A study commissioned by Action Aid determines that there has been a significant reduction in most people's income. ${ }^{18}$

\section{Mozambique in focus}

Mozambique has been reporting high rates of economic growth and attracting a significant flow of FDI, particularly for the mining and agricultural sectors. In order to examine the impacts of mining and agro-fuel projects on the local rural population, FIAN International conducted a research visit to Mozambique from 26 August till 2 September 2009. The visit was carried out following the invitation of the National Organization of Mozambican Peasants (UNAC). ${ }^{19}$ The research team visited the Massingir district in the Gazaprovince to look into the impacts of the sugarcane ethanol project ProCana on the social rights of the local communities. According to information gathered on this, the ProCana project was supposed to invest approx. US\$510 million in 30,000hectares of land and would supposedly be the largest of its kindin Mozambique. ${ }^{20}$

\footnotetext{
${ }^{16}$ Information about this case can be found at: http://face-it-act-now.org/ml/documents/dossier-the-casemubende/document ${ }^{17}$ The term 'Washington Consensus' was initially used in 1989 by John Williamson to describe a set of ten specific economic policy prescriptions that he considered should constitute the "standard" reform package promoted for crisis-wracked developing countries by Washington, D.C.-based institutions such as the International Monetary Fund (IMF), World Bank, and the US Treasury Department

${ }^{18}$ See Plan for Modernization of Agriculture: Eradicating poverty in Uganda, The Republic of Uganda, 2000,page vi. Available athttp://www.pma.go.ug/pdfs/Plan\%20for\%20Modernisation\%20of\%20Agriculture.pdf

${ }^{19}$ See http://www.biofuelsdigest.com/blog2/2008/01/29/mozambique-president-sets-biofuels-objectives-nodiversion-of-foodproduction-all-refining-in-mozambique/, accessed on 27 November 2009.

${ }^{20}$ See Ethanol's African Land Grab - Mozambique has survived colonialism and civil war. But can it survive the ethanol industry? By Adam Welz . Available at http://www.motherjones.com/environment/2009/03/ethanolsafrican-landgrab?page=2 48
} 
The British company Bio-Energy Africa bought from the Central African Mining and Exploration Company (CAMEC) and another unknown investor 94 percent of the project in $2008 / 2009,{ }^{21}$ forming a joint venture with national investors as well. However, in late 2009, it announced suspension of investment in ProCana, in order to preserve cash and focus on mining exploration and development in sub-Saharan Africa. ${ }^{22}$ According to information from the $22^{\text {nd }}$ of December 2009, the government cancelled the ProCana project, and it has no legal existence in Mozambique anymore. The Government claims that the company did not fulfill the original intentions submitted and approved by the Government in 2007.For the Mozambican Government, the ProCana land can now be considered available for further development by any company who wishes to invest in agriculture under government-approved terms. While it appears that the CAMEC-controlled Procana project is officially closed now, the key insights that can be drawn from this experience remain critical and relevant not only for the fate of this 30,000 hectares and the people who live there, but for the broader issue of global land grab and agro-fuels development more generally.

\section{Discussing Ethiopia}

Ethiopia is a very poor country, with extremely important problems of hunger and food aid dependency. Agriculture is a key sector for the economy of the country, as it represents half of its gross domestic production. While information on the land grabbing case mentions 528,000ha of land that are being bought or leased by foreign investors in Ethiopia, the figures given by the government itself seem to be much higher. Although it is true that this difference can partly be explained by not all the land being made available by the Ethiopian government finding an investor, it also indicates that the estimates given by the table are probably largely underestimated. In any case, whatever the figures chosen, these figures reveal the relative importance of foreign investments, as up to $4 \%$ of the fertile land (according to the government's estimation of fertile lands) in Ethiopia could become exploited by foreign entities. This would represent the equivalent of up to $8.5 \%$ of the total current agricultural area (including permanent meadows and pastures), and the equivalent of up to $20 \%$ of the current arable land and permanent crops area. However, estimating the impact foreign land acquisition has had on the landownership structure is difficult to make. The figures given can cover different realities. The government indicates that, as at 2009, '14 to 18 million hectares' of land are currently being exploited for agriculture, while the FAO evaluated in2007 at 35 million hectares the 'agricultural land'. The difference largely comes from the fact that the government does not take into account the permanent meadows and pastures. The ministry of agriculture thus declared that when a land used for pasture would be given to foreign investors, the pastoralists who used this land would not be compensated, as 'they should go somewhere else'. ${ }^{23}$ Equally, it is not sure what the figure of 74.5 million hectares of fertile land in Ethiopia covers: it could include large areas of forest, and damages to the environment have already been reported. ${ }^{24}$ The land is, up to recently and traditionally, in its great majority exploited by small-scale farmers (95 to 98\%). The massive foreign investments are made on huge areas, and they are thus substantially modifying the land ownership structure and the correlated social structure and cultural practices. There is little information about which kind of land is given to the investors, whether it is vacant land or whether the land is currently being used by peasant farmers or pastoralists. The reality is probably both, but whether we choose one approximation or the other, and still assuming that foreign investments are all made on wide-scale areas, the proportion of wide-scale exploitations (>10ha) in Ethiopia could move from $1.4 \%$ (census 2001-2002) to a figure comprised between $17 \%$ and $20 \%$ in the next years if the Ethiopian government's plan were to be completed. Yet, as described previously, the move towards wide-scale agriculture is empirically hardly identical of better access to food for the local population. This is all the more true as foreign companies usually invest in such land either for profit (and thus selling to countries that pay the most), or to export to high income countries that are having growing demands in terms of foods. ${ }^{25}$ This is only one example amongst many others. Other countries, like Zambia, are in a similar situation.

\footnotetext{
${ }^{21}$ See Programme for Basic Energy and Conservation - Saving energy for a better future, ProBEC Biofuel newsletter \# 20, September 2009, www.proBEC.org

${ }^{22}$ See Ethanol's African Land Grab - Mozambique has survived colonialism and civil war. But can it survive theethanol industry?By Adam Welz, available at http://www.motherjones.com/environment/2009/03/ethanolsafrican-landgrab?page=2

${ }^{23}$ See http://www.biofuelsdigest.com/blog2/2008/01/29/mozambique-president-sets-biofuels-objectives-nodiversion-of-foodproduction-all-refining-in-mozambique/, accessed on 27 November 2009.

${ }^{24}$ See Vermeulen, Sonja and Lorenzo Cotula. 'Over the heads of local people: consultation, consent and recompense in largescale land deals for biofuels projects in Africa'. Paper under review, Journal of Peasant Studies. 2009.

${ }^{25}$ See Manuel, Lino and AldaSalomão. „Biofuels and land rights in Mozambique - the ProCana case“.Haramata54. March 2009, p. 17-19.
} 
According to the organization AGTER ${ }^{26}$, the Zambian government is seeking to transfer 30 million hectares to foreign investors, in a country of only 70 million hectares. It is equally evaluated that only $14 \%$ of the arable land is currently being cultivated, which probably again ignores traditional pastures and other small-scale farming. ${ }^{27}$

\section{Discussing medium of Exchange: Employment opportunities}

Governments, IFIs and private investors argue that land commercialization/investment can create new employment opportunities in rural areas. They believe increased access to the job market can compensate for the loss of land in terms of securing people's livelihoods. Many observe however that a large share of these jobs are of poor quality and conditions, badly paid and targeted mainly to low-skilled seasonal agricultural workers. ${ }^{28}$ The Special Rapporteur on the right to food recognizes that 'those working in agriculture are a large part of the hungry' and calls for protecting agricultural worker rights: 'Farm workers must earn a living wage to get access to food. ${ }^{, 29}$ According to ILO, the number of people working in agriculture in Africa is increasing, even though its share in total employment has declined in recent years. In general, "difficult working conditions, low pay, violence and harassment, including sexual harassment, are all too common in agricultural work. Despite some instances of improved income brought by export opportunities, the expansion of world trade in agricultural products has failed to translate into better living conditions for most of those working in farming in the developing world. ${ }^{30}$ Moreover, some fear that due to increasing mechanization in agro-fuels production, there is a risk that the number of agricultural jobs would decrease over time. The ${ }^{31}$ International Food Policy Research Institute (IFPRI) observes that depending on how they are managed 'the conversion of land to large-scale farms or plantation 'generates little employment for local skilled or unskilled labor'/

${ }^{32}$ The case of the workers in the flower plantation Rosebud in Uganda demonstrates this point. Rosebud belongs to the Ruparelia Group, one of the biggest flower exporting companies. Last November Safari Mazirani, member of the Uganda Horticultural and Allied Workers' Union (UHAWU died as a consequence of a pesticide accident on January 8 , 2010. The company had not provided him with proper medical treatment at the time of being exposed to the pesticide. It also did not compensate him for the accident nor his family for his death. Two days before he died, UHAWU protested about the working conditions at Rosebud, in particular low payment, insufficient protective clothing, sexual harassment and insufficient maternity protection. The trade union demanded immediate improvement of their working conditions. Since the company did not address these complaints, the workers went on sit-down strike on 26, January 2010. The strike however was disbanded after the company called in the police. ${ }^{33}$ National and international actors should rather not assume that land commercialization/investment will lead to sustainable and long term employment opportunities for those affected.

\footnotetext{
${ }^{26}$ See Foreign Direct Investment in the Agricultural Sector in Ethiopia, EcoFair Trade Dialogue: Discussion paper No 12 by Lucie Weissleder, University of Bonn, Heinrich Boll Stiftung, Misereor, October 2009. Available at http://www.ecofairtrade.org/pics/en/FDIs_Ethiopia_15_10_09_c.pdf

${ }^{27} \mathrm{FAO}$ defines arable land as the land under temporary agricultural crops (multiple-croppedareas are counted only once), temporary meadows for mowing or pasture, land undermarket and kitchen gardens and land temporarily fallow (less than five years). Theabandoned land resulting from shifting cultivation is not included in this category. Data for"Arable land" are not meant to indicate the amount of land that is potentially cultivable.

${ }^{28}$ See Biofuels, Opportunity or Threat to the Poor, Swiss Agency for Development and Cooperation, Issue Paper, 2007. Available http://www.coet.udsm.ac.tz/biofuel\%20documents/Mayte07\%20\%20Issue\%20Paper\%20Biofuels_SDC\%20NRU.pd

${ }^{29}$ See Political will needed to tackle food crisis and restructure agriculture UN Press Release on the SpecialRapporteur on the Right to Food presentation of his second report to the Human Rights Council, 18 September2009. Available athttp://www.unhchr.ch/huricane/huricane.nsf/view01/3CC7EDFFEE12CD0AC12576350035B11A?opendocument

${ }^{30}$ Organizing for Social Justice.Global Report under the Follow-up to the ILO Declaration on FundamentalPrinciples and Rights at Work.International Labour Conference, 92nd Session. ILO, Geneva 2004.Para 117.Available at: .

${ }^{31}$ For the problems agricultural workers face in the realization of their right to food, seeAgribusiness and the right to food. Report of the Special Rapporteur on the right to food, Olivier de Schutter.Human Rights Council.Thirteenth session. $\mathrm{A} / \mathrm{HRC} / 13 / 33$

${ }^{32}$ See 'Land Grabbing' by Foreign Investors in Developing Countries: Risks and Opportunities by Joachim vonBraun and Ruth Meinzen-Dick, IFPRI Policy Brief, April 09. Available at http://www.landcoalition.org/pdf/ifpri_land_grabbing_apr_09.pdf

${ }^{33}$ See letter campaign TödlicherPestizidunfall in Uganda - Briefaktion Rosebud. Available at:

http://www.fian.de/online/index.php?option=com_content\&view=article\&id=271:toedlicher-pestizidunfall-inugandabriefaktion-qrosebudq\&catid=1:aktuelle-nachrichten $\&$ Itemid $=620$ 


\section{Land grab as breeding ground for Conflict}

By putting unprecedented pressures on land resources, the global trends described above are placing new tensions on access to land. Potential for conflict is further exacerbated by the ambiguity surrounding land rights. A company's legal rights over land may not be perceived as legitimate by the local populations and vice versa. In a presentation to a round table at the General Assembly, the World Bank recognized the potential for conflict given the lack of clear demarcation of communities' land rights, inadequate data, failure to consult effectively with the affected communities and a lack of transparency. ${ }^{34}$ Conflict over access to natural resources is nothing new as evidenced by the ongoing conflict in the Democratic Republic of the Congo for instance. Such conflicts often lead to widespread displacement. Given the predominance of agriculture and sustainable land access as a means of livelihood in Africa, displacements often lead to hunger and in some cases famine. In 2000, FIAN for instance documented how conflict over natural resources in Sudan and the response of the State led to the rural poor being unable to feed themselves, and to widespread famine. ${ }^{35}$ In May 2007 in Kampala, in Uganda, two protestors were killed and an Asian stoned to death during massive demonstrations against Government plans to convert thousands of hectares of rainforest on an island in Lake Victoria into an oil-palm plantation. The demonstrations developed into an ugly race riot and clearly 'brought into the open the simmering conflict' over the use of Uganda's natural resources. ${ }^{36}$ In Cameroon in January 2003, a violent confrontation between guards and villagers/indigenous populations erupted when a number of guards prevented villagers/indigenous populations from using SOCOPALM's plantation resources. ${ }^{37}$ The public outcry in Madagascar over the proposed land deal with South Korea's Daewoo Corporation equally illustrates the depth of emotions attached to land issues and the potential for violence and political conflict.

\footnotetext{
${ }^{34}$ See Securing Land Tenure and Improving Livelihoods: Towards a Set of Principles for Responsible Agroinvestment World Bank Presentation to the Roundtable "Promoting Responsible International Investment in Agriculture" held concurrently with The 64th United Nations General Assembly New York City, 23 September2009. ${ }^{36}$ See The New Scramble for Africa, Seedling, GRAIN, July 2007. Available athttp://www.grain.org/seedling/?id=481\#

${ }^{37}$ See World Rainforest Bulletin No 134, September 2008. By Julien-François Gerber. This article is based on the author's field observation and on the following publications: M.A., Monfort 2005, "Filièresoléagineusesafricaines", Notes et étudeséconomiques, ${ }^{\circ} 23$, p. 55-85; Agir ICI \&Survie, 2000, "Le silence de la forêt:réseaux, mafias et filière bois au Cameroun", Dossiers Noirs n ${ }^{\circ} 14$, and "Bolloré: monopoles, services compris. Tentaculesafricaines", Dossiers Noirs $n^{\circ} 15$, Paris, L'Harmattan. Available at http://www.wrm.org.uy/bulletin/134/viewpoint.html\#\%20Cameroon:\%20 Bagyeli\%20severely\%20impacted\%20by\%20the\%20establishment $\% 20$ of $\% 20$ industrial\%20plantations.
} 